\title{
Functional Redundancy and Specialization of the Conserved Cold Shock Proteins in Bacillus subtilis
}

\author{
Patrick Faßhauer ${ }^{1}$, Tobias Busche ${ }^{2}$, Jörn Kalinowski ${ }^{2}$, Ulrike Mäder ${ }^{3} \mathbb{D}$, Anja Poehlein ${ }^{4}\left(\mathbb{D}\right.$, Rolf Daniel ${ }^{4}(\mathbb{D}$ \\ and Jörg Stülke $1, * \mathbb{D}$
}

1 Department of General Microbiology, GZMB, Georg-August-University Göttingen, 37077 Göttingen, Germany; patrick.fasshauer@uni-goettingen.de

2 Center for Biotechnology (CeBiTec), Bielefeld University, 33615 Bielefeld, Germany; tbusche@cebitec.uni-bielefeld.de (T.B.); joern@cebitec.uni-bielefeld.de (J.K.)

3 Interfaculty Institute for Genetics and Functional Genomics, University Medicine Greifswald, 17487 Greifswald, Germany; ulrike.maeder@uni-greifswald.de

4 Department of Genomic and Applied Microbiology, GZMB, Georg-August-University Göttingen, 37077 Göttingen, Germany; apoehle3@gwdg.de (A.P.); rdaniel@gwdg.de (R.D.)

* Correspondence: jstuelk@gwdg.de; Tel.: +49-551-3933781

Citation: Faßhauer, P.; Busche, T.; Kalinowski, J.; Mäder, U.; Poehlein, A.; Daniel, R.; Stülke, J. Functional Redundancy and Specialization of the Conserved Cold Shock Proteins in Bacillus subtilis. Microorganisms 2021, 9, 1434. https://doi.org/10.3390/ microorganisms 9071434

Academic Editor: Imrich Barák

Received: 3 June 2021

Accepted: 30 June 2021

Published: 2 July 2021

Publisher's Note: MDPI stays neutral with regard to jurisdictional claims in published maps and institutional affiliations.

Copyright: (c) 2021 by the authors. Licensee MDPI, Basel, Switzerland. This article is an open access article distributed under the terms and conditions of the Creative Commons Attribution (CC BY) license (https:/ / creativecommons.org/licenses/by/ $4.0 /)$.

\begin{abstract}
Many bacteria encode so-called cold shock proteins. These proteins are characterized by a conserved protein domain. Often, the bacteria have multiple cold shock proteins that are expressed either constitutively or at low temperatures. In the Gram-positive model bacterium Bacillus subtilis, two of three cold shock proteins, $\mathrm{CspB}$ and $\mathrm{CspD}$, belong to the most abundant proteins suggesting a very important function. To get insights into the role of these highly abundant proteins, we analyzed the phenotypes of single and double mutants, tested the expression of the csp genes and the impact of CspB and CspD on global gene expression in B. subtilis. We demonstrate that the simultaneous loss of both $\mathrm{CspB}$ and $\mathrm{CspD}$ results in a severe growth defect, in the loss of genetic competence, and the appearance of suppressor mutations. Overexpression of the third cold shock protein CspC could compensate for the loss of $\mathrm{CspB}$ and $\mathrm{CspD}$. The transcriptome analysis revealed that the lack of CspB and CspD affects the expression of about $20 \%$ of all genes. In several cases, the lack of the cold shock proteins results in an increased read-through at transcription terminators suggesting that $\mathrm{CspB}$ and CspD might be involved in the control of transcription termination.
\end{abstract}

Keywords: Bacillus subtilis; cold shock proteins; quasi-essential

\section{Introduction}

Bacillus subtilis is the model organism for a large group of Gram-positive bacteria, among them serious pathogens and biotechnologically relevant bacteria. Due to this relevance, B. subtilis is one of the best-studied organisms. However, for about $25 \%$ of all proteins, the function is completely unknown, or the proteins are only poorly characterized [1]. Similarly, in the artificially created genome of the minimal organism Mycoplasma mycoides JCVI-syn3.0, about one-third of all encoded proteins are of unknown function [2]. These numbers demonstrate how far we are from a complete understanding of even seemingly simple model organisms.

We are interested in a comprehensive understanding of B. subtilis. Obviously, the large fraction of unknown proteins is a major challenge. Among the unknown and poorly characterized proteins, the large majority is not or only weakly expressed under standard growth conditions and probably only important under very specific conditions [3]. However, among the 100 most abundant proteins, there are six proteins for which no clear function has been identified [4]. These highly abundant unknown proteins are likely to be of major relevance for the cell, and their functional analysis should be given a high priority. Among these proteins are the cold shock proteins $\mathrm{CspB}$ and $\mathrm{CspD}$, which are thought to act as RNA chaperones in B. subtilis [5]. The cold shock proteins are a large protein family 
that are all characterized by a conserved cold shock domain (see [6] for a phylogenetic tree). Among the bacteria, the cold shock proteins are nearly ubiquitous, and most bacteria encode multiple cold shock proteins. B. subtilis has three cold shock proteins, CspB, CspC, and CspD. The genes encoding the B. subtilis cold shock proteins are highly expressed under a wide variety of growth conditions, and with 31,200 and 21,500 protein molecules per cell, CspB and CspD, respectively, even belong to the 15 most abundant proteins in $B$. subtilis $[4,7]$.

The presence of multiple closely related proteins in an organism always raises the question of whether they participate in the same function or if their specific activity is slightly different. There are a few examples of families of closely related proteins in $B$. subtilis. In the case of $\mathrm{ABC}$ transporters or classic amino acid and ion transporters, both functional overlaps, as well as specific functions, have been observed [8-10]. In some cases, as described for the three diadenylate cyclases, all proteins have the same enzymatic activity, but their expression and activities are differentially controlled [11,12]. Similarly, the four DEAD-box RNA helicases have distinct domains in addition to the active protein core, and these proteins have independent functions [13]. Finally, in some cases, regulatory systems consisting of multiple parts, such as two-component regulatory systems, ECF sigma factors, PTS-controlled RNA-binding antitermination proteins, or stress signaling proteins, specificity is achieved by co-evolving interacting partners of these systems [14-17].

For the B. subtilis cold shock proteins, it has been observed that the bacteria are not viable in the absence of all three proteins [5]. This, on the one hand, supports the idea that these highly abundant proteins play a major role in the B. subtilis cell and, on the other hand, suggests that there is at least some functional overlap between them. In Staphylococcus aureus, the CspA protein is unique among the three cold shock proteins since it is the only one that is strongly constitutively expressed and important for the expression of the virulence factor staphyloxanthin $[18,19]$. It was shown that a single amino acid in CspA, a conserved proline residue, is responsible for this regulatory effect [18].

To get more insights into the function(s) of the cold shock proteins of B. subtilis, we studied their expression as well as phenotypes of mutants. The deletion of $\operatorname{csp} B$ and $\operatorname{csp} D$ was found to result in the rapid acquisition of suppressor mutations that often result in increased expression of $\operatorname{csp} C$, suggesting that $\mathrm{CspC}$ might at least partially take over the function of CspB and CspD if it is overexpressed. We also studied the global RNA profile of a strain lacking CspB and CspD and observed that these proteins are important for transcription elongation and termination and that they can control the read-through at transcription terminators.

\section{Materials and Methods}

\subsection{Bacterial Strains, Growth Conditions, and Phenotypic Characterization}

All B. subtilis strains used in this study are listed in Table 1. All strains are derived from the laboratory strain 168 (trpC2). B. subtilis was grown in Lysogeny Broth (LB medium) [20]. LB plates were prepared by addition of $17 \mathrm{~g}$ Bacto agar/l (Difco) [20,21]. Quantitative studies of lacZ expression in B. subtilis were performed as described previously [20]. One unit of $\beta$-galactosidase is defined as the amount of enzyme which produces $1 \mathrm{nmol}$ of o-nitrophenol per min at $28^{\circ} \mathrm{C}$. 
Table 1. B. subtilis strains used in this study.

\begin{tabular}{|c|c|c|}
\hline Strain & Genotype & Source or Reference \\
\hline 168 & $\operatorname{trpC2}$ & Laboratory collection \\
\hline GP1968 & $\operatorname{trp} C 2 \Delta \operatorname{csp} B:: c a t$ & This study \\
\hline GP1969 & $\operatorname{trp} C 2 \Delta \operatorname{csp} C::$ spec & This study \\
\hline GP1970 & $\operatorname{trpC} 2 \Delta \operatorname{csp} B::$ cat $\Delta \operatorname{csp} C:: s p e c$ & This study \\
\hline GP1971 & $\operatorname{trp} C 2 \Delta \operatorname{csp} B:: c a t \Delta \operatorname{cspD}:: a p h A 3$ & This study \\
\hline GP1972 & $\operatorname{trpC2} \Delta \operatorname{csp} \mathrm{C}:: \operatorname{spec} \Delta \operatorname{cspD}:: \operatorname{aph} A 3$ & This study \\
\hline GP1984 & trpC2 amyE::($\left(\mathrm{P}_{c s p C}-l a c Z\right.$ cat $)$ & pGP3117 $\rightarrow 168$ \\
\hline GP1986 & $\operatorname{trp} C 2$ amyE::($\left(\mathrm{P}_{c s p C}[\mathrm{G}-65 \mathrm{~A}]-\mathrm{lacZ}\right.$ cat $)$ & pGP3119 $\rightarrow 168$ \\
\hline GP1989 ${ }^{1}$ & $\operatorname{trpC2} \Delta \operatorname{csp} B:: c a t \Delta \operatorname{cspD}:: a p h A 3 \mathrm{P}_{\operatorname{csp} C}-[\mathrm{G}-65 \mathrm{~A}]$ & This study \\
\hline GP1990 ${ }^{1}$ & $\operatorname{trpC2} \Delta \operatorname{csp} B:: \operatorname{cat} \Delta \operatorname{csp} D:: \operatorname{aph} A 3 \mathrm{P}_{\text {veg }}[\mathrm{G}-10 \mathrm{~T}]$ & This study \\
\hline GP2614 & $\operatorname{trpC2} \triangle \operatorname{cspD::aphA3}$ & [22] \\
\hline GP2888 & $\operatorname{trp} C 2 \Delta v e g:: \operatorname{erm} C$ & This study \\
\hline GP2896 & $\operatorname{trp} C 2 \Delta$ veg::ermC $\Delta \operatorname{csp} D:: a p h A 3$ & GP2888 $\rightarrow$ GP2614 \\
\hline GP2897 & $\operatorname{trpC2} \Delta$ veg::ermC $\Delta \operatorname{cspB}::$ cat $\Delta \operatorname{csp} D::$ aphA3 & GP1968 $\rightarrow$ GP2896 \\
\hline GP2898 & trpC2 amyE::( $\mathrm{P}_{\text {veg }}$-lacZ cat $)$ & pGP3133 $\rightarrow 168$ \\
\hline GP2899 & 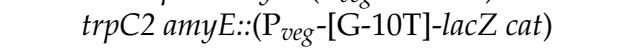 & pGP3134 $\rightarrow 168$ \\
\hline GP2900 ${ }^{1}$ & $\operatorname{trp} C 2 \Delta \operatorname{csp} B:: c a t \Delta \operatorname{csp} D:: a p h A 3 \operatorname{degS}[\mathrm{P} 245 \mathrm{~S}]$ & This study \\
\hline GP3251 & $\operatorname{trp} C 2 \Delta \operatorname{csp} B::$ tet & This study \\
\hline GP3274 & $\operatorname{trp} C 2 \operatorname{csp} C-\mathrm{A} 58 \mathrm{P}-\mathrm{spec} \Delta \operatorname{csp} D:: a p h A 3$ & This study \\
\hline GP3275 & $\operatorname{trp} C 2 \operatorname{cspC-A} 58 \mathrm{P}$-spec $\Delta \operatorname{csp} B:$ :tet $\Delta \operatorname{csp} D:: a p h A 3$ & GP3251 $\rightarrow$ GP3274 \\
\hline GP3283 & $\operatorname{trpC2}$ amyE::($\left(\mathrm{P}_{c s p B}-\right.$ lacZ cat $)$ & pGP3136 $\rightarrow 168$ \\
\hline GP3286 & $\operatorname{trpC2}$ amyE::($\left(\mathrm{P}_{c s p D}\right.$-lacZ-cat $)$ & This study \\
\hline
\end{tabular}

${ }^{1}$ The genomic DNA of these strains was analyzed by whole-genome sequencing.

\subsection{DNA Manipulation and Genome Sequencing}

B. subtilis was transformed with plasmids, genomic DNA, or PCR products according to the two-step protocol $[20,21]$. Transformants were selected on LB plates containing erythromycin $(2 \mu \mathrm{g} / \mathrm{mL})$ plus lincomycin $(25 \mu \mathrm{g} / \mathrm{mL})$, chloramphenicol $(5 \mu \mathrm{g} / \mathrm{mL})$, kanamycin $(10 \mu \mathrm{g} / \mathrm{mL})$, tetracycline $(12.5 \mu \mathrm{g} / \mathrm{mL})$, or spectinomycin $(250 \mu \mathrm{g} / \mathrm{mL})$. S7 Fusion DNA polymerase (Biozym, Hessisch Oldendorf, Germany) was used as recommended by the manufacturer. DNA fragments were purified using the QIAquick PCR purification kit (Qiagen, Hilden, Germany). DNA sequences were determined by the dideoxy chain termination method [21]. Chromosomal DNA from B. subtilis was isolated using the peqGOLD Bacterial DNA Kit (Peqlab, Erlangen, Germany). To identify the mutations in the suppressor mutant strains GP1989, GP1990, and GP2900, the genomic DNA was subjected to whole-genome sequencing as described previously [3]. The reads were mapped on the reference genome of B. subtilis 168 (GenBank accession number: NC_000964) [23]. Mapping of the reads was performed using the Geneious software package (Biomatters Ltd., Auckland, New Zealand) [24]. The resulting genome sequences were compared to that of our in-house wild-type strain. Single nucleotide polymorphisms were considered as significant when the total coverage depth exceeded 25 reads with a variant frequency of $\geq 90 \%$. All identified mutations were verified by PCR amplification and Sanger sequencing.

\subsection{Construction of Translational LacZ Reporter Gene Fusions}

Plasmid pAC5 [25] was used to construct translational fusions of the $\operatorname{csp} B, \operatorname{csp} C$, and veg promoter regions with the lac $Z$ gene. For this purpose, the respective promoter regions were amplified using the oligonucleotide pairs PF151/PF152 (cspB, corresponds to $379 \mathrm{bp}$ upstream and $5 \mathrm{bp}$ downstream of the ATG start codon, respectively), PF97/PF98 (cspC, $237 \mathrm{bp}$ upstream, $125 \mathrm{bp}$ downstream), and PF127/PF118 (veg, $280 \mathrm{bp}$ upstream, $50 \mathrm{bp}$ downstream), and chromosomal DNA of B. subtilis 168 as the template. The PCR products were digested with EcoRI and BamHI and cloned into pAC5 linearized with the same enzymes. The resulting plasmids were pGP3136, pGP3117, and pGP3133 for the $\operatorname{csp} B$, $\operatorname{csp} C$, and veg promoters, respectively. Plasmids pGP3119 and pGP3134 for the $\operatorname{cspC}$ and veg mutant upstream regions were constructed accordingly using chromosomal DNA of 
the suppressor mutants GP1986 and GP1990 as the template, respectively. The promoter region of $\operatorname{cspD}$ (194 bp upstream, $30 \mathrm{bp}$ downstream) was fused to lacZ using a PCR product constructed with oligonucleotides PF246/PF247 and PF250/PF251 using pAC5 as a template and PF248/PF249 with chromosomal DNA from B. subtilis 168 as a template. The fragments were joined and amplified in a PCR as described previously for the deletion of genes [26,27]. The fusion constructs were integrated into the amyE site of the B. subtilis chromosome by the transformation of B. subtilis 168 with linearized plasmids or the PCR product. The resulting strains were GP3283 ( $\operatorname{csp} B$ wild type promoter), GP1984 ( $\operatorname{csp} C$ wild type promoter), GP1986 (cspC mutant promoter), GP3286 (cspD wild type promoter), GP2898 (veg wild type promoter), and GP2899 (veg mutant promoter).

\subsection{Construction of Mutants}

Deletion of the csp genes was achieved by transformation with PCR products constructed using oligonucleotides (see Table S1) to amplify DNA fragments flanking the target genes and intervening antibiotic resistance cassettes as described previously $[26,27]$. The strain GP3274 harboring the CspC-A58P variant was created using the multiple-mutation reaction method, as described previously [28], to generate the $\operatorname{csp} C$ fragment followed by the combination of the fragment with the downstream flanking region and a spectinomycin resistance cassette as described above.

\subsection{RNA-Sequencing}

B. subtilis 168 wild type and the $\operatorname{csp} B \operatorname{csp} D$ double mutant GP1971 were grown in LB medium to an $\mathrm{OD}_{600}$ of 0.2 and were harvested by mixing them $5: 3$ with frozen killing buffer ( $20 \mathrm{mM}$ Tris- $\mathrm{HCl} \mathrm{pH} 7.5,6 \mathrm{mM} \mathrm{MgCl}_{2}, 20 \mathrm{mM} \mathrm{NaN}_{3}$ ) followed by snap-freezing of the pellets in liquid nitrogen. RNA isolation and quality assessment were performed as described previously [7] with an additional DNase I treatment using TURBO DNase (Ambion). The RNA quality was checked by Trinean Xpose (Trinean, Gentbrugge, Belgium) and the Agilent RNA Nano 6000 kit using an Agilent 2100 Bioanalyzer (Agilent Technologies, Böblingen, Germany). The Ribo-Zero rRNA Removal Kit (Bacteria) from Illumina (San Diego, CA, USA) was used to remove the rRNA. The TruSeq Stranded mRNA Library Prep Kit from Illumina was applied to prepare the cDNA libraries. Final libraries were sequenced paired-end on an Illumina MiSeq system (San Diego, CA, USA) using 75 bp read length.

Trimmed reads were mapped to the B. subtilis 168 genome sequences (NCBI GenBank accession number AL009126.3) using Bowtie2 [29]. The annotation AL009126.3 from the NCBI RefSeq database was augmented with the RNA features previously annotated [7]). In order to perform differential gene expression analysis, DEseq2 [30] was used as a part of the software ReadXplorer v2.2 [31]. Statistically significant expression changes (adjusted $p$-value $\leq 0.01)$ with $\log 2$ fold change $>1.0$ or $<-1.0$ were used. RNA-seq data have been deposited in the ArrayExpress database at EMBL-EBI (www.ebi.ac.uk/arrayexpress (accessed on 2 July 2021)) under accession number E-MTAB-10658.

\subsection{Qualitative PCR and Real-Time Quantitative Reverse Transcription PCR}

For RNA isolation, the cells were grown in LB medium and harvested at an $\mathrm{OD}_{600}$ of 1.2 for qualitative PCR and an $\mathrm{OD}_{600}$ of $0.5-0.8$ for quantitative RT-PCR. Preparation of total RNA was carried out as described previously [32]. cDNAs for qualitative PCR were synthesized using the RevertAid First Strand cDNA Synthesis Kit from ThermoFisher according to the manufacturer's instructions. cDNAs for qRT-PCR were synthesized using the One-Step RT-PCR kit (BioRad, Feldkirchen, Germany) as described [33]. qRT-PCR was carried out on the iCycler instrument (BioRad), following the manufacturer's recommended protocol by using the primers indicated in Table S1. The rpsE and rpsJ genes encoding constitutively expressed ribosomal proteins were used as internal controls. Data analysis and the calculation of expression ratios as fold changes were performed as described [33]. qRT-PCR experiments were performed in triplicate. 


\subsection{Microscopy}

For microscopy, cells were grown at $37{ }^{\circ} \mathrm{C}$ in liquid LB medium overnight. The overnight culture was directly used for microscopy or for inoculation of LB medium, which was incubated at $37^{\circ} \mathrm{C}$ to an $\mathrm{OD}_{600}$ of 0.3-0.5. Images were acquired using an Axioskop 40 FL fluorescence microscope, equipped with digital camera AxioCam MRm and AxioVision Rel (version 4.8, Carl Zeiss, Oberkochen, Germany) software for image processing (Carl Zeiss, Göttingen, Germany) and Neofluar series objective at $\times 100$ primary magnification.

\section{Results}

\subsection{Relative Contribution of the Cold Shock Proteins to the Growth of B. subtilis}

It has been reported that $B$. subtilis is not viable in the absence of the three cold shock proteins $\mathrm{CspB}, \mathrm{CspC}$, and $\mathrm{CspD}$ [5]. To get better insights into the role(s) of the individual cold shock proteins, we constructed a set of single and double mutants. In agreement with the published data, deletion of all three csp genes was not possible. First, we compared the growth of the strains on plates at $37^{\circ} \mathrm{C}$ and $15^{\circ} \mathrm{C}$. As shown, in Figure 1A, at $37^{\circ} \mathrm{C}$, all single mutants, as well as the $\operatorname{cspB} \operatorname{csp} C$ and $\operatorname{csp} C \operatorname{csp} D$ double mutants, grew indistinguishable from the wild-type strain $B$. subtilis 168 . In contrast, the $\operatorname{csp} B \operatorname{csp} D$ double mutant GP1971 barely formed colonies; instead, this mutant acquired suppressor mutations that restored growth (Figure 1A, see below). At $15^{\circ} \mathrm{C}$, growth of the $\operatorname{csp} B \operatorname{csp} C$ double mutant was also strongly impaired comparable to the $\operatorname{csp} B \operatorname{csp} D$ double mutant (Figure 1B), whereas the $\operatorname{csp} C \operatorname{csp} D$ double mutant showed a slight growth defect.

A

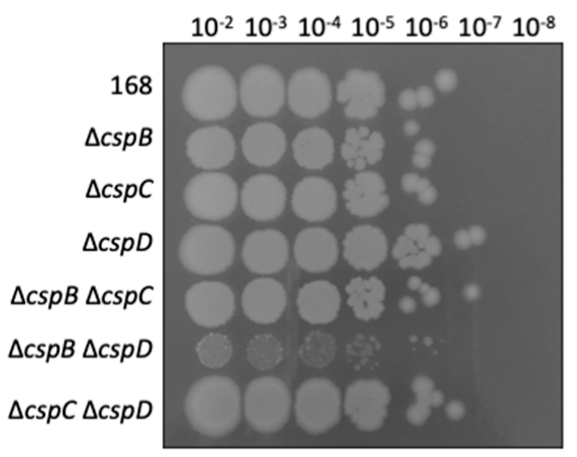

LB, $37^{\circ} \mathrm{C}$

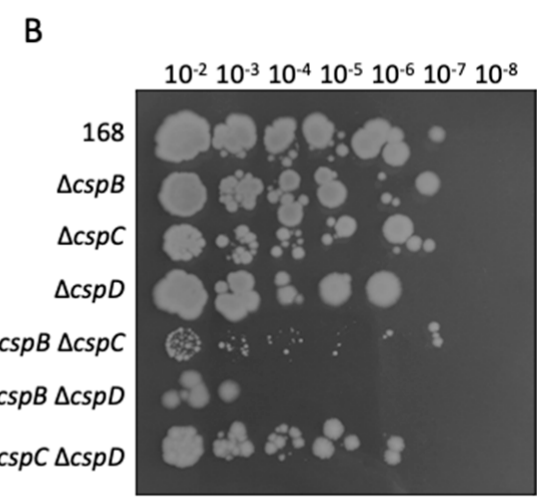

$\mathrm{LB}, 15^{\circ} \mathrm{C}$

Figure 1. Growth of $\operatorname{csp}$ knockout mutants. The wild-type strain B. subtilis 168 and the csp mutants GP1968 ( $\Delta c s p B), \mathrm{GP} 1969(\Delta c s p C), \mathrm{GP} 2614(\Delta c s p D), \mathrm{GP} 1970(\Delta c s p B \Delta c s p C), \mathrm{GP} 1971(\Delta c s p B \Delta c s p D)$, and GP1972 $(\Delta \operatorname{csp} C \Delta \operatorname{csp} D)$ were cultivated on LB-agar $(\mathbf{A})$ at $37^{\circ} \mathrm{C}$ for one day and $(\mathbf{B})$ at $15^{\circ} \mathrm{C}$ for 11 days. The results are representative of three biological replicates.

Microscopic analysis of the cell morphologies of the different csp mutant strains indicated that the cold shock proteins did not affect cell morphology during logarithmic growth (see Figure 2A). Similarly, loss of $c s p C$ or $c s p D$ did not affect the morphology in the stationary phase. In contrast, the deletion of $\operatorname{cspB}$ in GP1968 resulted in the formation of elongated cells in the stationary phase suggesting a defect in cell wall biosynthesis and/or cell division or in the entry to stationary phase (Figure 2B). The $\operatorname{csp} B \operatorname{csp} D$ double mutant showed a highly aberrant cell morphology with curly cells in the stationary phase (see Figure 2B). The strong phenotype of the $\operatorname{csp} B \operatorname{csp} D$ double mutant is in good agreement with the poor growth of this mutant. 
A

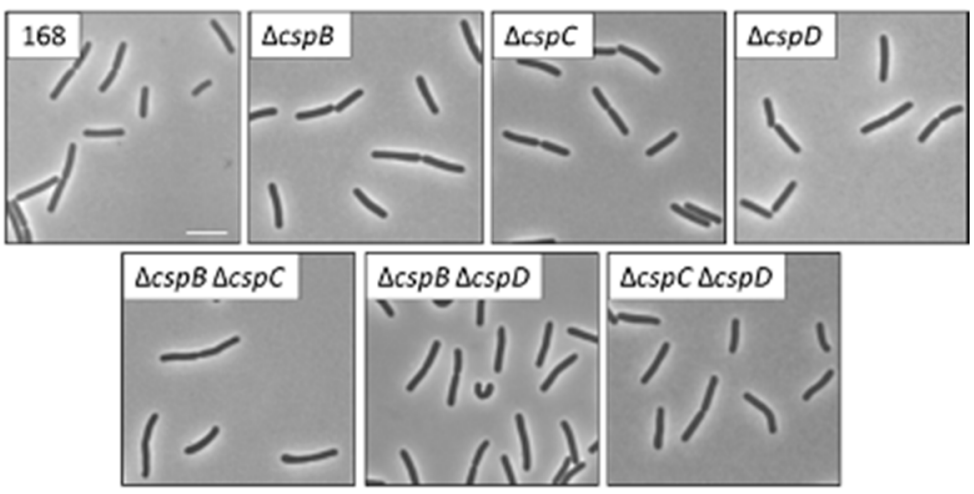

B

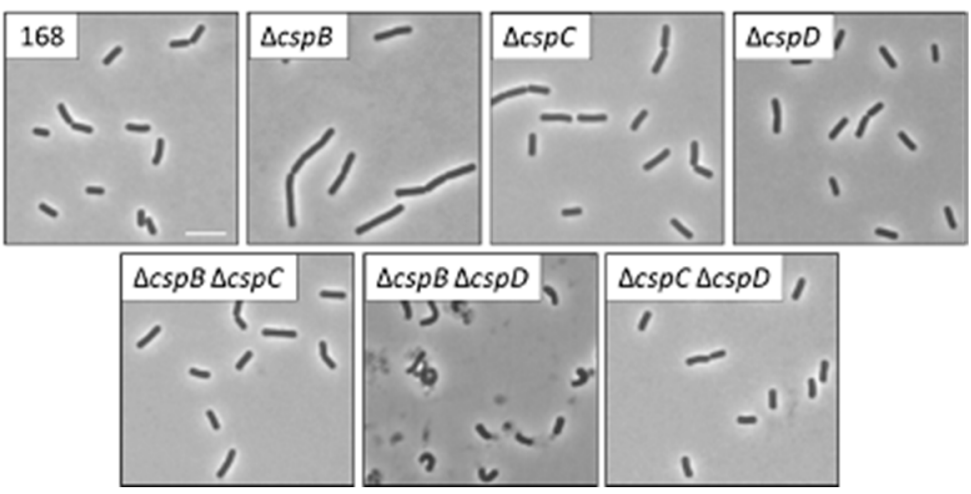

Figure 2. Phenotypic analysis of $B$. subtilis csp mutants. The wild-type strain B. subtilis 168 and the csp mutants GP1968 ( $\Delta c s p B)$, GP1969 $(\Delta c s p C)$, GP2614 $(\Delta c s p D)$, GP1970 ( $\Delta \operatorname{csp} B \Delta c s p C)$, GP1971 $(\Delta \operatorname{csp} B$ $\Delta c s p D)$, and GP1972 $(\Delta c s p C \Delta c s p D)$ were analyzed for morphology by phase-contrast microscopy. Scale bars, $5 \mu \mathrm{M}$. (A) Cells were cultivated in liquid LB medium at $37^{\circ} \mathrm{C}$ to an $\mathrm{OD}_{600}$ of $0.3-0.5$. (B) Cells were cultivated in liquid LB medium at $37^{\circ} \mathrm{C}$ overnight to the stationary growth phase.

In our attempts to combine the different mutations by genetic transformation, we observed that the $\operatorname{cspB} \operatorname{csp} D$ double mutant GP1971 had completely lost genetic competence, whereas all single mutants, as well as the other double mutants, were not affected.

Taken together, these data indicate that none of the individual cold shock proteins is essential for the viability of B. subtilis. Moreover, strains expressing either CspB or CspD exhibited few phenotypic effects. In contrast, the simultaneous loss of the latter two proteins had drastic consequences for growth, cell morphology, and genetic competence. This suggests that the two proteins have similar and overlapping activities and that their function cannot be taken over by CspC.

In several cases, such as for diadenylate cyclases and undecaprenyl pyrophosphate phosphatases of $B$. subtilis, the proteins have very similar functions but are unable to replace each other because they are expressed under different conditions [12,34,35]. In contrast, all cold shock genes are highly expressed under all conditions [1,7], and CspB and CspD do even belong to the most abundant proteins in B. subtilis [4]. To get more insights into the expression of the three $\operatorname{cs} p$ genes in B. subtilis, we constructed and analyzed fusions of their promoter regions to a promoterless lac $Z$ reporter gene encoding $\beta$-galactosidase. As shown in Table 2, all three genes were highly expressed at both $15^{\circ} \mathrm{C}$ and $37^{\circ} \mathrm{C}$. However, the expression of the $\operatorname{csp} B$ and $\operatorname{cspD}$ genes did not respond to the temperature, whereas $\operatorname{cs} p C$ expression was about five times higher at $15^{\circ} \mathrm{C}$ as compared to the expression at $37^{\circ} \mathrm{C}$. Thus, based on the expression response to temperature, only $\operatorname{csp} C$ can be called a cold shock protein. The high constitutive expression of $\operatorname{csp} B$ and $\operatorname{csp} D$ is in excellent agreement with the central function of the encoded proteins in B. subtilis. 
Table 2. Promoter activities of the B. subtilis csp genes.

\begin{tabular}{cccc}
\hline Strain & Promoter & Enzyme Activity in Units/Mg of Protein \\
\hline & & $15^{\circ} \mathrm{C}$ & $37^{\circ} \mathrm{C}$ \\
\hline GP3283 & $\operatorname{csp} B$ & $14,900 \pm 1680$ & $11,750 \pm 560$ \\
GP1984 & $\operatorname{csp} C$ & $30,950 \pm 2900$ & $6320 \pm 280$ \\
GP3286 & $c s p D$ & $11,300 \pm 1600$ & $19,600 \pm 450$ \\
\hline
\end{tabular}

a All measurements were performed in triplicate. The standard deviations are indicated.

\subsection{Suppressor Analysis of the CspB CspD Double Mutant}

As mentioned above, the $\operatorname{cspB} \operatorname{csp} D$ double mutant GP1971 was impaired in growth and formed suppressor mutants after two days of incubation on plates. In order to get more insights into the function of these cold shock proteins, we isolated and characterized a set of suppressor mutants that was able to grow in the absence of CspB and CspD. Three of these mutants were subjected to whole-genome sequencing. Each of the strains carried a single point mutation. In the case of strain GP1989, we identified a point mutation upstream of the $\operatorname{csp} C$ gene. Strain GP1990 had a mutation upstream of the constitutively expressed veg gene, and GP2900 carried a mutation affecting the sensor kinase DegS that resulted in a substitution of Pro- 245 by serine. We then analyzed three additional suppressor mutants for mutations in the $\operatorname{csp} C$ and veg upstream regions as well as in the deg $S$ coding sequence. They all carried mutations upstream of $\operatorname{csp} C$, highlighting the importance of this mutation, whereas no mutations potentially affecting veg and $\operatorname{deg} S$ were found. Since the csp genes are not part of the regulon controlled by the DegS-DegU two-component system, we focused our further analyses on the mutations in the upstream regions of $\operatorname{csp} C$ and veg.

In four suppressor mutants, we found single point mutations in the $5^{\prime}$ untranslated region of the $\operatorname{csp}$ C gene (RNA feature S179 [7]). The $5^{\prime}$ UTRs of $\operatorname{csp} B$ and $\operatorname{csp} C$ contained two conserved regions that were dubbed cold shock boxes [5]. The identified mutations in the $\operatorname{csp} C$ upstream regions were located in one of the cold shock boxes or very close to it (see Figure 3). We assumed that these mutations might affect the expression of $\operatorname{cspC}$. To test this idea, we fused the G-65A control region of the mutant strain GP1989 to the lac $Z$ reporter gene lacking its own transcription and translation signals and compared the expression of the lac $Z$ gene to that driven by the wild type control region. For this purpose, the strains GP1984 and GP1986 carrying the lacZ gene under the control of the wild type and mutant $\operatorname{csp} C$ upstream regions, respectively, were cultivated in LB medium at $37^{\circ} \mathrm{C}$, and the resulting $\beta$-galactosidase activities were determined. For the wild type, we observed $4360( \pm 210)$ units of $\beta$-galactosidase activity per mg of protein, whereas the activity was increased to $9450( \pm 710)$ units for the mutant $\operatorname{csp} C$ upstream region. This indicates that the mutation resulted in higher $\operatorname{csp} C$ expression, which in turn is likely to be the reason for the suppression of the $\operatorname{csp} B \operatorname{csp} D$ double mutant.

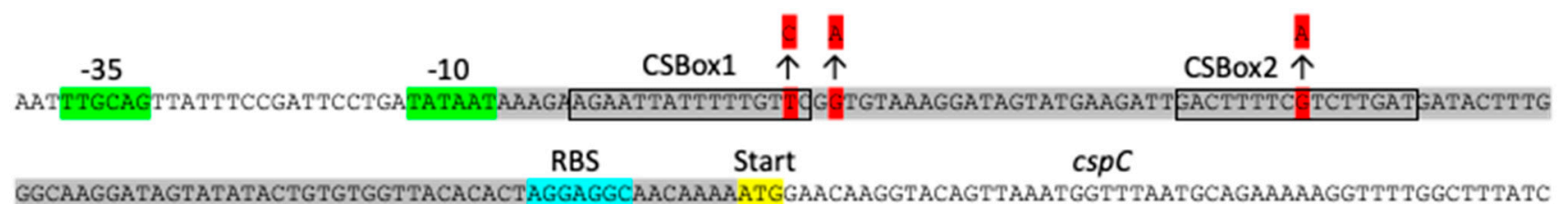

Figure 3. Genetic organization of the $\operatorname{csp} C$ promoter region. Sequence of the promoter region showing the -35 and -10 regions. The 5'UTR (RNA feature S179) is highlighted in grey. CSBoxes, cold shock boxes; RBS, ribosomal binding site; mutations found in $\triangle \operatorname{csp} B \Delta \operatorname{csp} D$ suppressor mutants are highlighted in red.

The mutation in the 5'UTR of veg affected the ribosomal binding site (GGUGGA $\rightarrow$ UGUGGA), suggesting reduced expression of the veg gene in the suppressor mutant GP1990. Again, we fused the wild type and mutant control regions of veg to the lacZ reporter gene and compared the $\beta$-galactosidase activities. For B. subtilis GP2898 (wild type), we observed $34( \pm 1)$ units of $\beta$-galactosidase activity per mg of protein. In contrast, 
the activity was reduced to $2( \pm 1)$ units of $\beta$-galactosidase for the lac $Z$ gene under the control of the mutant veg 5' UTR in GP2899. This indicates that a reduced expression of the veg gene might help to overcome the deleterious effect of the simultaneous loss of the two major cold shock proteins. To test this idea, we combined the veg gene deletion with the $\operatorname{csp} B \operatorname{csp} D$ deletion and observed the growth of the strains on complex medium. While the $\operatorname{csp} B \operatorname{cspD}$ double mutant GP1971 grew only poorly, growth was restored both if the expression of the veg gene was reduced or if the veg gene was deleted (Figure 4). These observations indicate that the Veg protein may play a role in RNA metabolism in B. subtilis, and that it becomes toxic in the absence of the major cold shock proteins.

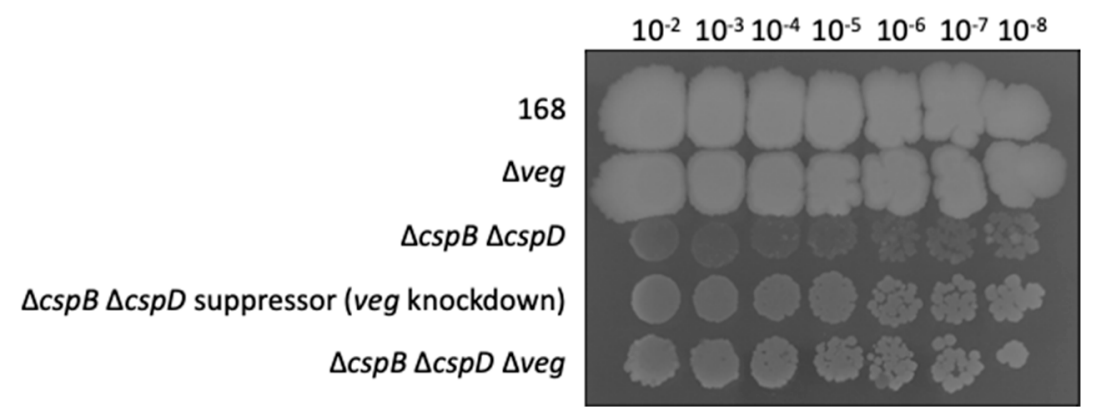

Figure 4. Growth of veg knockdown and knockout mutants in the $\Delta \operatorname{csp} B \Delta \operatorname{csp} D$ background. The wildtype strain B. subtilis 168, GP2888 ( $\Delta v e g)$, GP1971 ( $\Delta c s p B \Delta c s p D)$, GP1990 ( $\Delta c s p B \Delta c s p D$ suppressor with knockdown mutation of veg), and GP2897 ( $\Delta \operatorname{csp} B \Delta \operatorname{csp} D \Delta v e g)$ were cultivated on LB-agar at $37^{\circ} \mathrm{C}$ for $36 \mathrm{~h}$. The results are representative of three biological replicates.

\subsection{A Modified CspC Protein Can Take over the Functions of CspB and CspD}

As mentioned above, the three cold shock proteins of B. subtilis are highly similar to each other. A recent study on the cold shock proteins of $S$. aureus identified the proline residue at position 58 in CspA as functionally important [18]. This residue is located on the protein's surface close to the RNA-binding site [18]. The corresponding residue conserved in B. subtilis CspB and CspD, but not in CspC. We, therefore, decided to replace the alanine present at this position in $\mathrm{CspC}$ with a proline residue and to assay whether the modified protein could compensate for the lack of $\mathrm{CspB}$ and $\mathrm{CspD}$. For this purpose, we combined the $\operatorname{csp} C(\mathrm{~A} 58 \mathrm{P})$ allele with the deletions of $\operatorname{cspB}$ and $\operatorname{cspD}$. The resulting strain was GP3275. We then compared GP3275 and the corresponding $\operatorname{cspB} \operatorname{cspD}$ double mutant GP1971 with respect to growth and genetic competence (see Figure 5). As shown, CspC-A58P could compensate for the loss of both $\mathrm{CspB}$ and $\mathrm{CspD}$ for growth, and partial compensation was observed for genetic competence. This indicates that native expression of the CspC-A58P variant is sufficient for the suppression of the $\operatorname{csp} B \operatorname{csp} D$ double mutant, similar to increased expression of the wild type CspC protein.
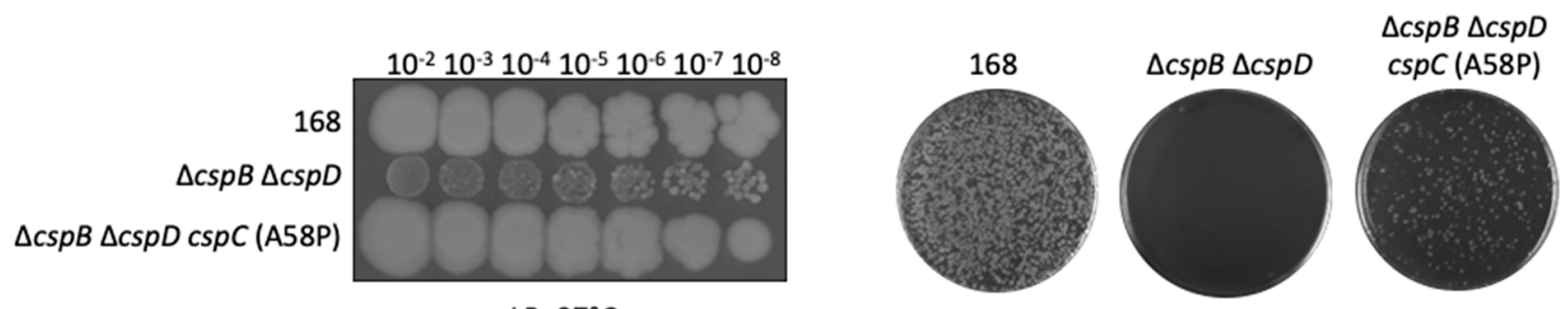

LB, $37^{\circ} \mathrm{C}$

Figure 5. The $\operatorname{csp} C(\mathrm{~A} 58 \mathrm{P})$ variant restores growth and genetic competence in the $\Delta \operatorname{csp} B \Delta \operatorname{cspD}$ background. The left panel shows the strains B. subtilis wild type 168, GP1971 $(\Delta \operatorname{csp} B \Delta \operatorname{csp} D)$, and GP3275 ( $\Delta \operatorname{csp} B \Delta \operatorname{cspD} \operatorname{csp} C$ (A58P) that were cultivated on LB-agar at $37^{\circ} \mathrm{C}$ for $36 \mathrm{~h}$. The right panel shows the transformants obtained after transformation an equal number of competent cells with $200 \mathrm{ng}$ of chrom. DNA. Data are representative of three biological replicates. 


\subsection{RNA-Seq Analysis Suggests a Role for Cold Shock Proteins in Transcription Termination and Elongation}

While it is clear from the data presented above that the cold shock proteins play a pivotal role in the physiology of $B$. subtilis, even at $37^{\circ} \mathrm{C}$, nothing is known about the specific functions of these proteins. A study on the E. coli cold shock proteins suggested that they act as transcriptional antiterminators [36]. To test whether the cold shock proteins of $B$. subtilis are involved in transcription as well, we performed an RNA-seq analysis with the wild-type strain and the $\operatorname{csp} B \operatorname{csp} D$ double mutant GP1971. This analysis allowed us to not only get insights into the regulation of the $B$. subtilis genes by the cold shock proteins but also to study their impact on the expression of intergenic regions. In total, 542 and 305 genes exhibited an increased and decreased expression in the $\operatorname{csp} B \operatorname{csp} D$ double mutant with more than twofold changes of expression. The most strongly affected transcription units (more than 20-fold change in expression) are listed in Table 3 (see Table S2 for the complete dataset). Among the most strongly upregulated genes were many involved in the utilization of different carbon sources. The most strongly downregulated genes were dominated by genes involved in aerobic and anaerobic regulation. The genes belong to the Rex and Fnr regulons (see Table 3).

Table 3. Effect of the deletion of $\operatorname{cspB}$ and $\operatorname{csp} D$ on the expression of $B$. subtilis genes and operons.

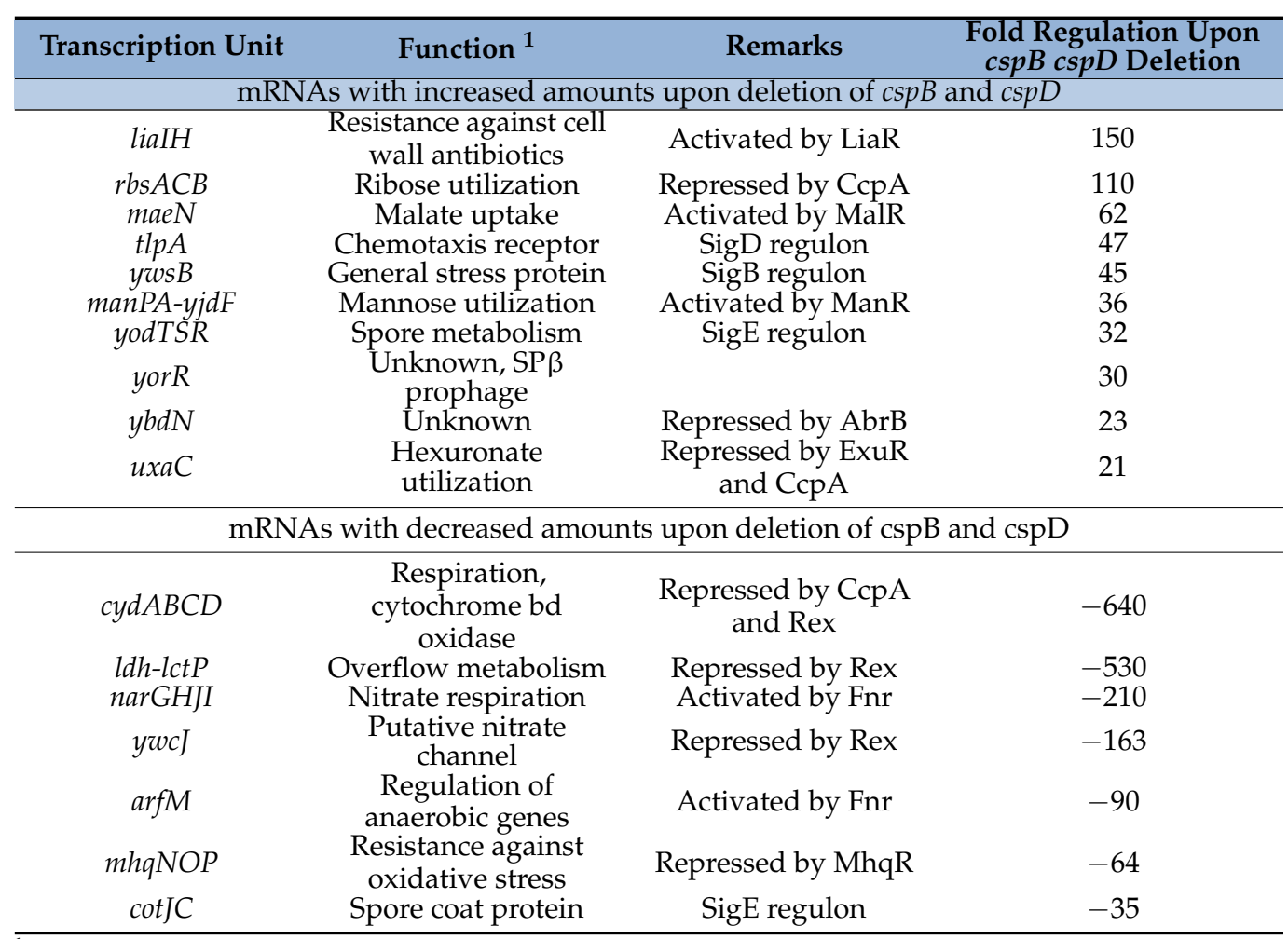

${ }^{1}$ Functional information is based on the SubtiWiki database [1].

As the E. coli Csp proteins act as transcriptional antiterminators, we also studied the expression of intergenic regions of the most strongly $\mathrm{CspB} / \mathrm{CspD}$ responsive genes. Strikingly, in several cases, we observed an increased read-through at transcriptional terminators in the double mutant, e.g., between the manR and manP genes and the $\mathrm{liaH}$ and $l i a G$ genes (see Figure 6). This finding suggests that CspB and CspD support termination instead of acting as antiterminators in these intergenic regions. In contrast, the lack of CspB and $\mathrm{CspD}$ resulted in reduced read-through at the transcription termination structures between the pyrR and pyrP and pyrP and pyrB genes. The regulation of transcription between these genes involves the binding of the PyrR protein to the intergenic regions in the presence of UMP or UTP. PyrR binding results in the termination of transcription between $\operatorname{pyr} R$ and $\operatorname{pyr} P$ and $\operatorname{pyr} P$ and $p y r B$ [37]. The reduced read-through in the absence 
of CspB and CspD allows two conclusions: the cold shock protein may either act as antiterminator proteins at the pyr operon, or they may interfere with the binding of PyrR to its target regions thus allowing a basal read-through in this operon.

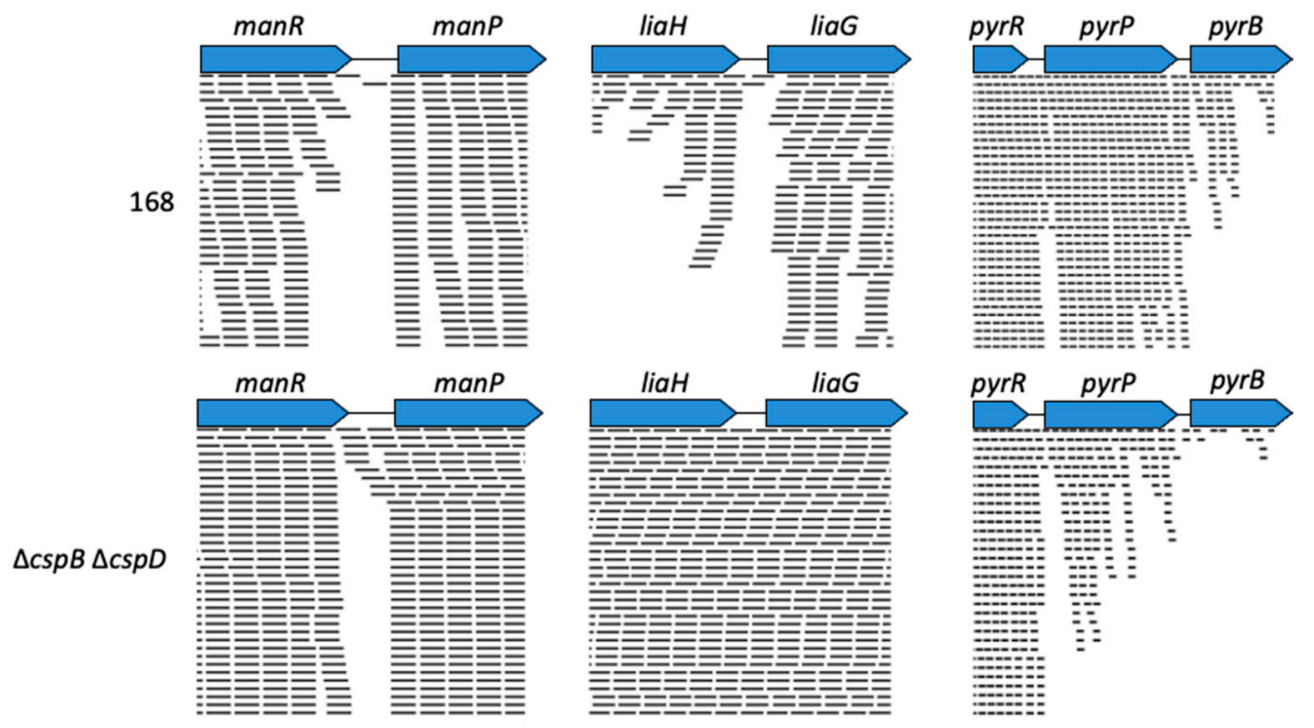

Figure 6. Differences in transcription in 168 and the $\Delta \operatorname{csp} B \Delta \operatorname{csp} D$ mutant. The intergenic regions between manR-manP, liaH-liaG, pyrR-pyrP-pyrB in B. subtilis wild type 168 (upper panel) and the $\Delta \operatorname{csp} B$ $\triangle c s p D$ mutant GP1971 (lower panel) aligned with the paired reads generated by RNA-sequencing are shown. The data are representative of three biological replicates. Pictures of aligned reads were created using the Geneious Software version 2020.0.4 (Biomatters Ltd., New Zealand).

\subsection{Analysis of Csp-Dependent Transcription Read-Through}

To verify the effect of $\mathrm{CspB}$ and $\mathrm{CspD}$ on transcription read-through, we performed PCR analyses for the intergenic regions of the man, the lia, and the pyr operons. For this purpose, total mRNA was converted to cDNA and used as a template for PCR assays. To make sure that the analysis was specific for the intergenic regions, we amplified regions covering 400 nucleotides upstream and downstream of the transcription terminators. As positive and negative controls, we used assays with chromosomal DNA as the template and assays with mRNA that had not been subjected to reverse transcription, respectively. As shown in Figure 7A, clear products corresponding to the manR-manR, liaH-liaG, pyrR-pyrP, and pyrP-pyrB intergenic regions could be observed if the PCR analysis was performed using the cDNA as a template. In the case of the man and lia operons, the intensity of these products was strongly increased for the $\operatorname{csp} B \operatorname{csp} D$ double mutant GP1971 as compared to the wild-type strain 168. In contrast, little effect of the inactivation of the $\operatorname{csp} B$ and $\operatorname{csp} D$ genes was detected for the intergenic regions of the pyr operon.

In order to get further evidence for the effect of $\mathrm{CspB}$ and $\mathrm{CspD}$ on read-through, we performed quantitative RT-PCR analyses for the intergenic regions (see Figure 7B). In agreement with the RNA-seq data and the qualitative PCR analysis, we observed increased read-through in the $\operatorname{cspB} \operatorname{cspD}$ double mutant for the manR-manP and liaH-liaG intergenic regions. For the intergenic regions of the pyr operon, we found reduced read-through, again in agreement with the RNA-seq data.

Thus, our results suggest that $\mathrm{CspB}$ and $\mathrm{CspD}$ are involved in the control of transcription elongation at terminator structures in B. subtilis; however, the increased expression level of the gene upstream of the terminator may also play a role in reduced termination in the $\operatorname{csp} B \operatorname{csp} D$ double mutant. 
A

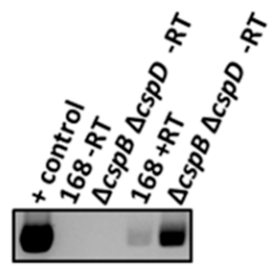

B

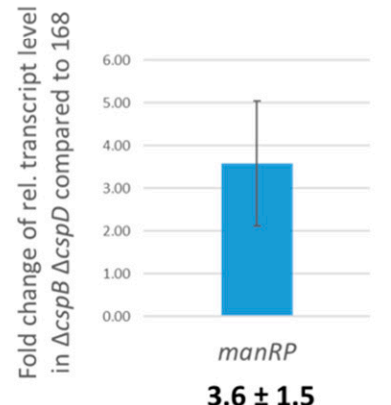

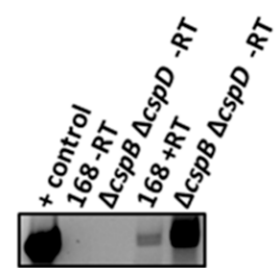

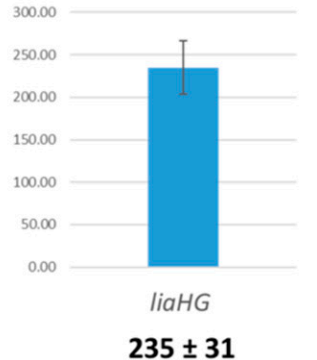

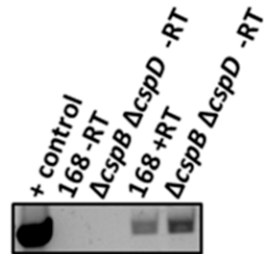

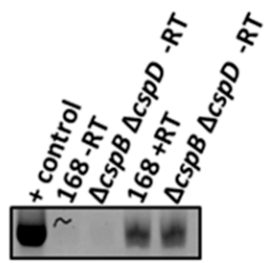

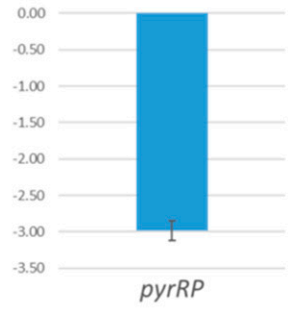

$-3.0 \pm 0.14$

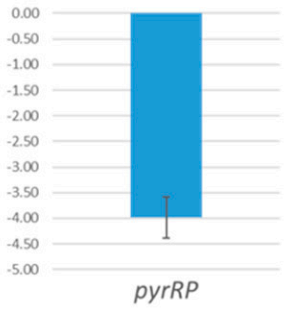

$-4.0 \pm 0.4$

Figure 7. Transcriptional read-through in 168 and the $\triangle \operatorname{csp} B \Delta \operatorname{csp} D$ mutant. (A) Qualitative PCR on read-through transcripts. Total RNA was extracted from 168 and GP1971. cDNA was synthesized and served as a template in a PCR with primers annealing up- and downstream of the terminators between manR-manP, liaH-liaG, pyrR-pyrP-pyrB. '+ control': standard PCR using chromosomal DNA of B. subtilis 168 as the template, '-RT': control sample without reverse transcriptase, '+RT': sample with reverse transcriptase. (B) Fold changes in the expression of read-through transcripts in a $\Delta \operatorname{csp} B \Delta \operatorname{cspD}(\mathrm{GP1971})$ mutant relative to levels in the wild-type strain (168) are shown. RNA was purified from each strain, and quantitative RT-PCR was performed using primer sets amplifying up- and downstream of the terminators in the indicated intergenic regions. Shown values represent the mean of three biological replicates. Errors bars indicate the standard deviations.

\section{Discussion}

Cold shock proteins are widespread among bacteria, and many species encode several of these proteins. This is exemplified by the actinobacterium Lentzea guizhouensis DHSC013 with as many as 15 distinct csp genes [38]. On the other side, some bacteria do not express any cold shock proteins. In the Bacilli, the proteins are ubiquitous, indicating that they are very important for the biology of these bacteria. Our results indicate that the cold shock proteins $\mathrm{CspB}$ and $\mathrm{CspD}$ performed a quasi-essential function in the cell and suggest that at least one of these proteins should be present in a minimal genome based on $B$. subtilis $[39,40]$.

B. subtilis encodes the three cold shock proteins CspB, CspC, and CspD. CspB and CspD are highly similar to each other ( $81 \%$ identical residues). CspC is also similar to both proteins, but the identical residues account only for $71 \%$ (with CspD) and $69 \%$ (with CspB). The evaluation of the expression as well as the analysis of mutants demonstrated that CspB and CspD are the key cold shock proteins. Actually, the term cold shock proteins is misleading since they are strongly constitutively expressed under a wide range of conditions [7]. Strains lacking one of the cold shock proteins had no or only slightly changed phenotype alterations as compared to the wild type. However, the concomitant loss of the highly similar and constitutively expressed proteins CspB and CspD had severe consequences: growth was strongly impaired, the cells had an aberrant morphology, and lost genetic competence. These observations suggest that $\mathrm{CspB}$ and $\mathrm{CspD}$ are functionally redundant: at least one of them is required, and a double mutant rapidly acquires suppressor mutations indicating that $\mathrm{CspB}$ and $\mathrm{CspD}$ together are quasi-essential for B. subtilis. In contrast, CspC seemed to play a major role at low temperatures: this was the only cold shock gene that was induced at low temperatures (see Table 2), and double mutants lacking CspC exhibited impaired growth at $15^{\circ} \mathrm{C}$. In the case of the $\operatorname{csp} B \operatorname{csp} C$ double mutant, the growth defect was as severe as observed for the $\operatorname{csp} B \operatorname{csp} D$ mutant, suggesting that $C \operatorname{spB}$ is more important than CspD. 
Even though CspC seems to be specialized distinctly as compared to CspB and CspD, we observed suppression of the $\operatorname{csp} B \operatorname{cspD}$ double mutant by overexpression of CspC, indicating that CspC can take over the function of the other proteins if it is present at high amounts. Similarly, we have observed suppression of a top $A$ mutant lacking the quasi-essential DNA topoisomerase I by overexpression of topoisomerase IV even though the two enzymes are specialized in distinct functions [41]. Interestingly, one amino acid exchange in $C \operatorname{spC}$ was sufficient to allow suppression of the $\operatorname{csp} B \operatorname{csp} D$ mutant even at a wild type expression rate: This mutation affects a conserved proline residue that was not present in CspC. Upon introduction of a proline in position 58 of $\mathrm{CspC}$, the protein can functionally replace $\mathrm{CspB}$ and $\mathrm{CspD}$, even with respect to genetic competence.

The suppressor analysis also identified the inactivation of the veg gene as sufficient to allow the growth of a strain lacking CspB and CspD. The precise function of the constitutively expressed Veg protein has not been identified, but a veg mutant was impaired in the expression of biofilm genes and biofilm formation [42]. Interestingly, the Veg protein was recently identified as an mRNA-associated protein in Clostridium difficile [22]. Suppression of the $\operatorname{csp} B \operatorname{csp} D$ double mutant by inactivation of Veg suggests that the proteins might act as antagonists.

Two lines of evidence suggest a function related to transcription for CspB and CspD: First, the corresponding E. coli proteins play a role in transcription initiation and antitermination [36,43]. Second, a B. subtilis strain lacking the quasi-essential endoribonuclease RNase $Y$ readily acquires mutations that affect the RNA polymerase and different transcription factors, such as the transcription elongation factor GreA and the RNA polymerase recycling factor RpoE. In addition to these mutations, inactivation of CspD was found to compensate for the lack of RNase Y [44]. Since all other suppressor mutants affected transcription in B. subtilis, it is likely that this was also the case for CspD. The analysis of the transcriptome of the $B$. subtilis $\operatorname{csp} B \operatorname{csp} D$ double mutant confirmed the involvement of these proteins in the expression of about $20 \%$ of all genes. The high resolution of the RNA-seq analysis allowed us to interrogate whether the cold shock proteins might have a function at transcription terminators. Indeed, we observed altered read-through at several transcription terminators in the $\operatorname{csp} B \operatorname{csp} D$ mutant. In contrast to the findings for E. coli, both our RNA-seq data as well as the PCR-based validation indicated that $\mathrm{CspB}$ and $\mathrm{CspD}$ favored transcription termination rather than antitermination.

Further studies will have to address the molecular interactions of the cold shock proteins and the specific role of CspC at optimal and low temperatures.

Supplementary Materials: The following are available online at https:/ / www.mdpi.com/article/ 10.3390/microorganisms9071434/s1, Table S1: Oligonucleotides used in this study. Table S2. Fold changes of the RNA-seq analysis of the cspB cspD double mutant GP1971 as compared to the wild type strain B. subtilis 168 .

Author Contributions: Conceptualization, P.F. and J.S.; methodology, P.F.; validation, P.F., A.P.; investigation, P.F., T.B., J.K., U.M. and R.D.; resources, J.S.; writing-original draft preparation, P.F. and J.S.; writing-review and editing, P.F., U.M. and J.S.; supervision, J.S.; funding acquisition, J.S. All authors have read and agreed to the published version of the manuscript.

Funding: This research was funded by the EU Horizons 2020 program (Grant Rafts4Biotech, 720776).

Institutional Review Board Statement: Not applicable.

Informed Consent Statement: Not applicable.

Data Availability Statement: RNA-seq data have been deposited in the ArrayExpress database at EMBL-EBI (www.ebi.ac.uk/arrayexpress, accessed on 2 July 2021) under accession number E-MTAB-10658.

Acknowledgments: We thank Marc Schaffer for excellent technical assistance.

Conflicts of Interest: The authors declare no conflict of interest. 


\section{References}

1. Michna, R.H.; Zhu, B.; Mäder, U.; Stülke, J. SubtiWiki 2.0—An integrated database for the model organism Bacillus subtilis. Nucleic Acids Res. 2016, 44, D654-D662. [CrossRef] [PubMed]

2. Hutchison, C.A.; Chuang, R.Y.; Noskov, V.N.; Assad-Garcia, N.; Deerinck, T.J.; Ellisman, M.H.; Gill, J.; Kannan, K.; Karas, B.J.; Ma, L.; et al. Design and synthesis of a minimal bacterial genome. Science 2016, 351, aad6253. [CrossRef] [PubMed]

3. Reuß, D.R.; Altenbuchner, J.; Mäder, U.; Rath, H.; Ischebeck, T.; Sappa, P.K.; Thürmer, A.; Guérin, C.; Nicolas, P.; Steil, L.; et al. Large-scale reduction of the Bacillus subtilis genome: Consequences for the transcriptional network, resource allocation, and metabolism. Genome Res. 2017, 27, 289-299. [CrossRef]

4. Eymann, C.; Dreisbach, A.; Albrecht, D.; Bernhardt, J.; Becher, D.; Gentner, S.; Tam, L.T.; Büttner, K.; Buurman, G.; Scharf, C.; et al. A comprehensive proteome map of growing Bacillus subtilis cells. Proteomics 2004, 4, 2849-2876. [CrossRef]

5. Graumann, P.; Wendrich, T.M.; Weber, M.H.W.; Schröder, K.; Marahiel, M.A. A family of cold shock proteins in Bacillus subtilis is essential for cellular growth and for efficient protein synthesis at optimal and low temperatures. Mol. Microbiol. 1997, 25, 741-756. [CrossRef] [PubMed]

6. Feliciano, J.R.; Seixas, A.M.M.; Pita, T.; Leitao, J.H. Comparative genomics and evolutionary analysis of RNA-binding proteins of Burkholderia cenocepacia J2315 and other members of the B. cepacia complex. Genes 2020, 11, 231. [CrossRef]

7. Nicolas, P.; Mäder, U.; Dervyn, E.; Rochat, T.; Leduc, A.; Pigeonneau, N.; Bidnenko, E.; Marchadier, E.; Hoebeke, M.; Aymerich, S.; et al. Condition-dependent transcriptome reveals high-level regulatory architecture in Bacillus subtilis. Science 2012, 335, 1103-1106. [CrossRef]

8. Gebhard, S. ABC transporters of antimicrobial peptides in Firmicutes bacteria-Phylogeny, function and regulation. Mol. Microbiol. 2012, 86, 1295-1317. [CrossRef] [PubMed]

9. Krüger, L.; Herzberg, C.; Rath, H.; Pedreira, T.; Ischebeck, T.; Poehlein, A.; Gundlach, J.; Daniel, R.; Völker, U.; Mäder, U.; et al. Essentiality of c-di-AMP in Bacillus subtilis: Bypassing mutations converge in potassium and glutamate homeostasis. PLoS Genet. 2021, 17, e1009092. [CrossRef] [PubMed]

10. Klewing, A.; Koo, B.M.; Krüger, L.; Poehlein, A.; Reuß, D.; Daniel, R.; Gross, C.A.; Stülke, J. Resistance to serine in Bacillus subtilis: Identification of the serine transporter YbeC and of a metabolic network that links serine and threonine metabolism. Environ. Microbiol. 2020, 22, 3937-3949. [CrossRef] [PubMed]

11. Commichau, F.M.; Heidemann, J.L.; Ficner, R.; Stülke, J. Making and breaking of an essential poison: The cyclases and phosphodiesterases that produce and degrade the essential second messenger cyclic di-AMP in bacteria. J. Bacteriol. 2019, 201, e00462-18. [CrossRef] [PubMed]

12. Mehne, F.M.P.; Schröder-Tittmann, K.; Eijlander, R.T.; Herzberg, C.; Hewitt, L.; Kaever, V.; Lewis, R.J.; Kuipers, O.P.; Tittmann, K.; Stülke, J. Control of the diadenylate cyclase CdaS in Bacillus subtilis: An autoinhibitory domain limits c-di-AMP production. J. Biol. Chem. 2014, 289, 21098-21107. [CrossRef] [PubMed]

13. Lehnik-Habrink, M.; Rempeters, L.; Kovács, Á.; Wrede, C.; Baierlein, C.; Krebber, H.; Kuipers, O.P.; Stülke, J. The DEAD-box RNA helicases in Bacillus subtilis have multiple functions and act independent from each other. J. Bacteriol. 2013, 195, 534-544. [CrossRef]

14. Procaccini, A.; Lunt, B.; Szurmant, H.; Hwa, T.; Weight, M. Dissecting the specificity of protein-protein interaction in bacterial two-component signaling: Orphans and crosstalks. PLoS ONE 2011, 6, e19729. [CrossRef] [PubMed]

15. Helmann, J.D. Bacillus subtilis extracytoplasmic function (ECF) sigma factors and defense of the cell envelope. Curr. Opin. Microbiol. 2016, 30, 122-132. [CrossRef] [PubMed]

16. Schilling, O.; Herzberg, C.; Hertrich, T.; Vörsmann, H.; Jessen, D.; Hübner, S.; Titgemeyer, F.; Stülke, J. Keeping signals straight in transcription regulation: Specificity determinants for the interaction of a family of conserved bacterial RNA-protein couples. Nucleic Acids Res. 2006, 34, 6102-6115. [CrossRef]

17. Pané-Farré, J.; Lewis, R.J.; Stülke, J. The RsbRST stress module in bacteria: A signalling system that may interact with different output modules. J. Mol. Microbiol. Biotechnol. 2005, 9, 65-76. [CrossRef] [PubMed]

18. Catalan-Moreno, A.; Caballero, C.J.; Irurzun, N.; Cuesta, S.; López-Sagaseta, J.; Toledo-Arana, A. One evolutionary selected amino acid variation is sufficient to provide functional specificity in the cold shock protein paralogs of Staphylococcus aureus. Mol. Microbiol. 2020, 113, 826-840. [CrossRef] [PubMed]

19. Catalan-Moreno, A.; Cela, M.; Mendenez-Gil, P.; Irurzun, N.; Caballero, C.J.; Caldelari, I.; Toledo-Arana, A. RNA thermoswitches modulate Staphylococcus aureus adaptation to ambient temperatures. Nucleic Acids Res. 2021, 49, 3409-3426. [CrossRef]

20. Kunst, F.; Rapoport, G. Salt stress is an environmental signal affecting degradative enzyme synthesis in Bacillus subtilis. J. Bacteriol. 1995, 177, 2403-2407. [CrossRef]

21. Sambrook, J.; Fritsch, E.F.; Maniatis, T. Molecular Cloning: A Laboratory Manual, 2nd ed.; Cold Spring Harbor Laboratory: Cold Spring Harbor, NY, USA, 1989.

22. Lamm-Schmidt, V.; Fuchs, M.; Sulzer, J.; Gerovac, M.; Hör, J.; Dersch, P.; Vogel, J.; Faber, F. Grad-seq identifies KhpB as a global RNA-binding protein in Clostrioides difficile that regulates toxin production. microLife 2021, 2, uqab004. [CrossRef]

23. Barbe, V.; Cruveiller, S.; Kunst, F.; Lenoble, P.; Meurice, G.; Sekowska, A.; Vallenet, D.; Wang, T.; Moszer, I.; Médigue, C.; et al. From a consortium sequence to a unified sequence: The Bacillus subtilis 168 reference genome a decade later. Microbiology 2009, 155, 1758-1775. [CrossRef] 
24. Kearse, M.; Moir, R.; Wilson, A.; Stones-Havas, S.; Cheung, M.; Sturrock, S.; Buxton, S.; Cooper, A.; Markowitz, S.; Duran, C.; et al. Geneious basic: An integrated and extendable desktop software platform for the organization and analysis of sequence data. Bioinformatics 2012, 28, 1647-1649. [CrossRef] [PubMed]

25. Martin-Verstraete, I.; Débarbouillé, M.; Klier, A.; Rapoport, G. Mutagenesis of the Bacillus subtilis "-12, -24" promoter of the levanase operon and evidence for the existence of an upstream activating sequence. J. Mol. Biol. 1992, 226, 85-99. [CrossRef]

26. Lehnik-Habrink, M.; Pförtner, H.; Rempeters, L.; Pietack, N.; Herzberg, C.; Stülke, J. The RNA degradosome in Bacillus subtilis: Identification of CshA as the major helicase in the multiprotein complex. Mol. Microbiol. 2010, 77, 958-971. [CrossRef] [PubMed]

27. Guérout-Fleury, A.M.; Shazand, K.; Frandsen, N.; Stragier, P. Antibiotic-resistance cassettes for Bacillus subtilis. Gene 1995, 167, 335-336. [CrossRef]

28. Hames, C.; Halbedel, S.; Schilling, O.; Stülke, J. MMR: A method for the simultaneous introduction of multiple mutations into the glpK gene of Mycoplasma pneumoniae. Appl. Environ. Microbiol. 2005, 71, 4097-4100. [CrossRef] [PubMed]

29. Langmead, B.; Trapnell, C.; Pop, M.; Salzberg, S.L. Ultrafast and memory-efficient alignment of short DNA sequences to the human genome. Genome Biol. 2009, 10, R25. [CrossRef] [PubMed]

30. Love, M.I.; Huber, W.; Anders, S. Moderated estimation of fold change and dispersion for RNA-seq data with DESeq2. Genome Biol. 2014, 15, 550. [CrossRef] [PubMed]

31. Hilker, R.; Stadermann, K.B.; Schwengers, O.; Anisiforov, E.; Jaenicke, S.; Weisshaar, B.; Zimmermann, T.; Goesmann, A. ReadXplorer 2-Detailed read mapping analysis and visualization from one single source. Bioinformatics 2016, 32, 3702-3708. [CrossRef] [PubMed]

32. Schilling, O.; Frick, O.; Herzberg, C.; Ehrenreich, A.; Heinzle, E.; Wittmann, C.; Stülke, J. Transcriptional and metabolic responses of Bacillus subtilis to the availability of organic acids: Transcription regulation is important but not sufficient to account for metabolic adaptation. Appl. Environ. Microbiol. 2007, 73, 499-507. [CrossRef] [PubMed]

33. Diethmaier, C.; Pietack, N.; Gunka, K.; Wrede, C.; Lehnik-Habrink, M.; Herzberg, C.; Hübner, S.; Stülke, J. A novel factor controlling bistability in Bacillus subtilis: The YmdB protein affects flagellin expression and biofilm formation. J. Bacteriol. 2011, 193, 5997-6007. [CrossRef] [PubMed]

34. Mehne, F.M.P.; Gunka, K.; Eilers, H.; Herzberg, C.; Kaever, V.; Stülke, J. Cyclic-di-AMP homeostasis in Bacillus subtilis: Both lack and high-level accumulation of the nucleotide are detrimental for cell growth. J. Biol. Chem. 2013, 288, 2004-2017. [CrossRef] [PubMed]

35. Zhao, H.; Sun, Y.; Peters, J.M.; Gross, C.A.; Garner, E.C.; Helmann, J.D. Depletion of undecaprenyl phosphatases disrupts cell envelope biogenesis in Bacillus subtilis. J. Bacteriol. 2016, 198, 2925-2935. [CrossRef]

36. Bae, W.; Xia, B.; Inouye, M.; Severinov, K. Escherichia coli CspA-family RNA chaperones are transcription antiterminators. Proc. Natl. Acad. Sci. USA 2000, 97, 7784-7789. [CrossRef] [PubMed]

37. Switzer, R.L.; Turner, R.J.; Lu, Y. Regulation of the Bacillus subtilis pyrimidine biosynthetic operon by transcriptional attenuation: Control of gene expression by an mRNA-binding protein. Prog. Nucleic Acid Res. Mol. Biol. 1999, 62, 329-367. [PubMed]

38. Galperin, M.Y.; Wolf, Y.I.; Makarova, K.S.; Vera Alvarez, R.; Landsman, D.; Koonin, E.V. COG database update: Focus on microbial diversity, model organisms, and widespread pathogens. Nucleic Acids Res. 2021, 49, D274-D281. [CrossRef]

39. Commichau, F.M.; Pietack, N.; Stülke, J. Essential genes in Bacillus subtilis: A re-evaluation after ten years. Mol. BioSyst. 2013, 9, 1068-1075. [CrossRef]

40. Reuß, D.R.; Commichau, F.M.; Gundlach, J.; Zhu, B.; Stülke, J. The blueprint of a minimal cell: MiniBacillus. Microbiol. Mol. Biol. Rev. 2016, 80, 955-987. [CrossRef]

41. Reuß, D.R.; Faßhauer, P.; Mroch, P.J.; Ul-Haq, I.; Koo, B.M.; Poehlein, A.; Gross, C.A.; Daniel, R.; Brantl, S.; Stülke, J. Topoisomerase IV can functionally replace all type 1A topoisomerases in Bacillus subtilis. Nucleic Acids Res. 2019, 47, 5231-5242. [CrossRef] [PubMed]

42. Lei, Y.; Oshima, T.; Ogasawara, N.; Ishikawa, S. Functional analysis of the protein Veg, which stimulates biofilm formation in Bacillus subtilis. J. Bacteriol. 2013, 195, 1697-1705. [CrossRef] [PubMed]

43. Giangrossi, M.; Brandi, A.; Gioliodori, A.M.; Gualerzi, C.O.; Pon, C.L. Cold-shock-induced de novo transcription and translation of infA and role of IF1 during cold adaptation. Mol. Microbiol. 2007, 64, 807-821. [CrossRef] [PubMed]

44. Benda, M.; Woelfel, S.; Fasshauer, P.; Gunka, K.; Klumpp, S.; Poehlein, A.; Kálalová, D.; Šanderová, H.; Daniel, R.; Krásný, L.; et al. Quasi-essentiality of RNase Y in Bacillus subtilis is caused by its critical role in the control of mRNA homeostasis. Nucleic Acids Res. 2021. [CrossRef] [PubMed] 